\title{
Peningkatan Kemampuan Penggunaan Kohesi Gramatikal dan Leksikal Melalui Teknik Graphic Organizer dalam Karangan Mahasiswa Pendidikan Bahasa Inggris Ikip Saraswati Tabanan
}

\author{
Cucu Ardiah Ningrum \\ cucuardiah280792@gmail.com \\ Madrasah Tsanawiah, Kediri Tabanan, Indoensia \\ I Wayan Simpen, Udayana University-Indonesia \\ wyn_simpen@unud.ac.id
}

\begin{abstract}
Abstrak
Penelitian ini dilakukan dengan tujuan untuk meningkatkan kemampuan penggunaan kohesi gramatikal dan leksikal pada karangan mahasiswa Jurusan Pendidikan Bahasa Inggris IKIP Sarasawati Tabanan. Tindakan kelas (PTK) dengan menggunakan graphic organizer sebagai teknik dalam mendukung kemampuan mahasiswa menggunakan alat-alat kohesi. Ad tiga tahapanan, yakni tahapanan pratindakan, siklus 1, dan siklus2. Pada tahapan pratindakan, penggunaan kohesi dalam karangan mahasiswa berjumlah 558 dari kalimat atau satuan topik sebanyak 195 buah. Dari total 558 kohesi, terdapat 439 penggunaan kohesi yang benar dan 119 penggunaan kohesi yang salah. Nilai rerata yang didapat pada tahapanan pratindakan ini adalah 78 dengan predikat baik (B). Pada pelaksanaan siklus 1 , penggunaan kohesi meningkat sebanyak 670 kohesi dari satuan topik sebanyak 3.702 kalimat. Pada tahapan ini, terdapat 610 penggunaan kohesi benar dan 87 penggunaan kohesi salah. Nilai rerata yang diperoleh mahasiswa adalah 88.2 dengan predikat amat baik (A). Peningkatan penggunaan kohesi berlanjut pada siklus 2 dengan penggunaan kohesi sebanyak 726 dari kalimat atau satuan topik sebanyak 3.842 buah. Penggunaan kohesi yang benar tercatat sejumlah 651 sementara kohesi yang salah sejumlah 75. Nilai rerata yang diperoleh mahasiswa adalah 89 dengan predikat amat baik (A).
\end{abstract}

\section{Kata kunci: kohesi gramatikal dan leksikal, graphic organizer, karangan mahasiswa}

\begin{abstract}
This study aims at improving the ability in using grammatical and lexical cohesion in essay created by students of English Education Department in IKIP Saraswati Tabanan. This study belongs to Classroom Action Research (CAR) using graphic organizer as technic in supporting students' ability in using cohesion devices. This study consists of three phases which are pre-action, cycle 1 and cycle 2 . In preaction phase, the use of cohesion devices in students' essays are 558 from 195 sentences. From that number, they are 439 corrected cohesion and 119 uncorrected cohesion. The approximate score for this phase is 78 which is categorized into Good (B). In the implementation of cycle 1, there is an improvement in grammatical and lexical cohesion used. The result of analysis shows that there are 670 cohesion used from 3702 sentences. In this cycle, there are 610 corrected cohesion and 87 uncorrected cohesion. The approximate score for students' essays in this cycle is 88.2 which is categorized into Excellent (A). The improvement of cohesion used continually occurs in cycle 2 . In this cycle, there are 726 cohesion used from 3842 sentences. The corrected cohesion devices are 651 noted while the uncorrected cohesion devices are 75. Based on this result, the approximate score for students' essays is 89 within the predicate Excellent (A).
\end{abstract}


Keywords: grammatical and lexical cohesion, graphic organizer, students' essay

\section{Pendahuluan}

Keberadaan kohesi dalam sebuah wacana merupakan faktor penting yang menentukan kualitas keterpaduan, kelogisan, dan keakuratan sebuah wacana sehingga pesan di dalamnya dapat ditangkap dengan baik oleh para pembaca. Menurut Nunan (1994) kohesi adalah kata atau frasa yang memungkinkan penulis atau pembicara menyusun hubungan antarkalimat atau antarujaran dan membantu mempertautkan kalimat-kalimat dalam sebuah teks sehingga kohesi dapat dipandang sebagai sebuah 'jembatan' penghubung antarkalimat atau ujaran dalam sebuah teks. Penggunaan kohesi yang tepat dapat menghasilkan tulisan yang bermutu dan berterima. Sebaliknya, kesalahan penggunaan kohesi dapat menimbulkan kejanggalan pada bentuk kalimat atau ujaran sehingga akan menghasilkan karangan atau wacana yang kurang berterima, baik dari segi tata bahasa maupun segi nilai estetika tulisan.

Dalam menghasilkan sebuah tulisan yang mengandung unsur kohesi, baik grammatikal maupun leksikal yang sesuai, bukan merupakan hal yang mudah. Seorang pembelajar bahasa seyogianya melatih kemampuan menulis secara intensif sehingga tidak hanya mampu mengembangkan ide dan daya imajinasi, tetapi juga menciptakan tulisan yang padu dan logis dengan memperhatikan penggunaan alat-alat kohesi dengan tepat. Salah satu target yang diharapkan mampu untuk menguasai keterampilan menulis dengan fasih adalah pembelajar bahasa asing, termasuk di dalamnya mahasiswa Jurusan Pendidikan Bahasa Inggris. Sebagai calon tenaga pengajar sekaligus seorang pembelajar bahasa asing, mahasiswa Jurusan Pendidikan Bahasa Inggris diwajibkan menguasai empat skill termasuk di dalamnya keterampilan menulis. Berkaitan dengan hal tersebut, dalam pelaksanaan proses perkuliahan terdapat mata kuliah writing untuk melatih dan mengembangkan keterampilan menulis mahasiswa.

Dalam pelaksanaannya, pemberian mata kuliah writing terhadap mahasiswa hanya berfokus pada kemampuan mahasiswa untuk mengenal berbagai genre tulisan tetapi tidak diberikan pemahaman secara mendalam terkait dengan unsur-unsur linguistik yang digunakan dalam tulisan. Persepsi ini diperkuat oleh hasil observasi yang telah dilakukan di salah satu perguruan tinggi berbasis pendidikan di Kabupaten Tabanan, yakni Institut Keguruan dan Ilmu Pendidikan (IKIP) Saraswati Tabanan. Berdasarkan hasil observasi yang telah dilakukan terkait pembelajaran mata kuliah writing, para peserta didik hanya diberikan pemahaman pada batasan jenis teks kemudian pengembangannya tanpa ada cakupan materi khusus yang mengajarkan penggunaan peranti kohesi dan hubungan koherensi antarkalimat sehingga kerap ditemukan tulisan-tulisan peserta didik yang memiliki topik yang menarik, tetapi kurang dalam pemaparannya. Seyogianya, kemampuan meramu kata-kata dan memproduksi hasil tulisan yang berterima akan menjadi bekal ketika mereka dihadapkan pada situasi proses mengajar yang sebenarnya.

Penelitian ini menitikberatkan penggunaan sebuah teknik yang akan mendukung peningkatan penggunaan alat-alat kohesi gramatikal dan leksikal dalam karangan mahasiswa Pendidikan Bahasa Inggris Semester III IKIP Saraswati Tabanan. Teknik yang digunakan dalam penulisan karangan adalah graphic organizer. Teknik ini membantu mahasiswa dalam menyusun kerangka berpikir dengan menerapkan pola tertentu yang digunakan sebagai pedoman pengembangan karangan. Dalam pengaplikasian 
teknik ini mahasiswa akan dibimbing untuk membuat skema atau kerangka berpikir seperti topik karangan, ide pokok, dan ide-ide penjelas dalam karangan. Dengan penggunaan teknik graphic organizer diharapkan mahasiswa dapat mengembangkan kemampuan menulis dengan berpedoman pada unsur linguistik terutama penggunaan alat-alat kohesi gramatikal dan leksikal

\section{Metode Penelitian}

Penelitian ini merupakan penelitian tindakan kelas (PTK) yang bertujuan untuk meningkatkan ketepatan penggunaan kohesi gramatikal dan leksikal pada karangan mahasiswa. Penelitian tindakan kelas (PTK) merupakan penelitian yang dilakukan secara langsung di dalam kelas untuk mengetahui pemasalahan yang muncul dalam proses pembelajaran sekaligus mengaplikasikan solusi terhadap permasalahan tersebut. Widayati (2008) menegaskan bahwa PTK merupakan kegiatan penelitian yang berkonteks kelas yang dilaksanakan untuk memecahkan masalahmasalah pembelajaran yang dihadapi oleh guru, memperbaiki mutu dan hasil pembelajaran dan mencobakan hal-hal baru dalam pembelajaran demi peningkatan mutu dan hasil pembelajaran.

Penelitian ini terdiri atas tiga tahapan yakni tahapan pratindakan, tahapan siklus 1 , dan tahapan siklus 2. Pada tahapan pratindakan mahasiswa hanya diinstruksikan untuk menulis karangan tanpa pemberian teknik pendukung. Data berupa karangan mahasiswa pada tahapan pratindakan dianalisis dan direfleksi untuk ditindaklanjuti sebagai dasar pelaksanaan siklus 1 dan siklus 2. Data hasil karangan mahasiswa dianalis secara kuantitatif dan kualitatif. Analisis kuantitatif dilakukan untuk mengetahui jumlah penggunaan kohesi yang benar dan salah serta persentase penggunaan alat kohesi. Selain itu, dijabarkan pula pemerolehan nilai mahasiswa berdasarkan hasil analisis karangan. Sementara itu analisis kualitatif dimaksudkan untuk memperoleh data terkait dengan proses pembelajaran mahasiswa, keaktifan menulis karangan, perspektif mahasiswa terkait dengan mata kuliah Writing III berdasarkan hasil kuesioner dan penjabaran data hasil analisis karangan.

\section{Landasan Teori}

Penelitian ini berfokus pada penggunaan kohesi gramatikal dan leksikal pada karangan mahasiswa. Teori yang digunakan sebagai landasan analisis karangan adalah teori Halliday dan Hasan (1976) tentang kohesi dan penggunaannya. Dalam buku mereka yang berjudul Cohession In English, Halliday and Hasan selanjutnya mengklasifikasikan kohesi menjadi dua kategori, yakni kohesi gramatikal dan kohesi leksikal. Peranti kohesi gramatikal meliputi konjungsi (conjunction), elipsis (ellipsis), substitusi (substitution), dan referensi (reference). Sementara peranti kohesi leksikal meliputi reiterasi (reiteration) dan kolokasi (collocation).

\section{Hasil dan Pembahasan}

Bab ini menjelaskan secara detail dan terperinci temuan-temuan yang merupakan hasil penelitian tindakan kelas (PTK) melalui penerapan teknik graphic organizer dalam meningkatkan kemampuan penggunaan alat-alat kohesi gramatikal dan leksikal dalam karangan mahasiswa.

\section{Penggunaan Peranti Kohesi Gramatikal dan Leksikal Karangan Mahasiswa pada Tahapan Pratindakan}

Tahapan ini merupakan awal penelitian yang bertujuan untuk melihat kemampuan mahasiswa dalam menggunakan kohesi gramatikal dan leksikal dalam penulisan sebuah karangan. Tahapan ini akan menentukan pengaplikasian siklus dan penerapan teknik yang tepat untuk diberikan kepada mahasiswa. Dalam tahapan ini terdapat rangkaian pelaksanaan penelitian yang diawali dengan persiapan observasi, implementasi pembelajaran, analisis kuantitatif 
dan kualitatif hasil karangan, dan refleksi kegiatan.

\section{Implementasi tahapan Pratindakan}

Dalam tahapan ini terdapat beberapa langkah yang dilakukan untuk mendapatkan data, yakni pengambilan data melalui kegiatan menulis dalam kelas "Writing", penyebaran kuesioner, dan dokumentasi. Terkait dengan pengambilan data melalui kegiatan, mahasiswa hanya diintruksikan untuk menulis sebuah karangan dengan tema bebas tanpa menerapkan teknik apa pun termasuk teknik graphic organizer.

\section{Analisis Kuantitatif tahapan Pratindakan}

Analisis kuantitatif pada tahapan pratindakan dimaksudkan untuk mengetahui persentase penggunaan kohesi oleh mahasiswa yang dijabarkan dalam bentuk tabel di bawah ini.

Tabel 1.1 Penggunaan Peranti Kohesi Karangan Mahasiswa pada tahapan Pratindakan

\begin{tabular}{llccc}
\hline No & $\begin{array}{l}\text { Peranti kohesi } \\
\text { gramatikal } \\
\text { dan leksikal }\end{array}$ & $\begin{array}{l}\text { Jumlah } \\
\text { Penggu } \\
\text { naan }\end{array}$ & $\begin{array}{l}\text { Perse } \\
\text { ntase }\end{array}$ & $\begin{array}{l}\text { Jumlah } \\
\text { Kalimat }\end{array}$ \\
\cline { 1 - 4 }$(1)$ & \multicolumn{1}{c}{$(2)$} & $(3)$ & $(4)$ & $(5)$ \\
\hline 1 & Reference & 297 & $53 \%$ & $\begin{array}{c}195 \\
\text { Kalimat }\end{array}$ \\
\hline 2 & Substitution & 1 & $0.2 \%$ & \\
\hline 3 & Ellipsis & 4 & $0.7 \%$ & \\
\hline 4 & Conjunction & 189 & $34 \%$ & \\
\hline 5 & Reiteration & 48 & $8.6 \%$ & \\
\hline 6 & Collocation & 19 & $3.4 \%$ & \\
\cline { 1 - 3 } & Jumlah & 558 & $100 \%$ & \\
\cline { 1 - 3 } & & &
\end{tabular}

Hasil analisis menunjukkan bahwa dalam tahapan ini terdapat penggunaan kohesi sebanyak 558 dari kalimat atau satuan topik sebanyak 195 buah. Penggunaan referensi dan konjungsi mendominasi karangan mahasiswa. Referensi menjadi alat kohesi terbanyak yang digunakan dengan persentase $53 \%$, sementara konjungsi menjadi kohesi kedua yang paling banyak digunakan dengan persentase $34 \%$. Substitusi dan ellipsis merupakan dua jenis kohesi gramatikal yang paling jarang digunakan. Sementara untuk kohesi leksikal, penggunaannya tidak terlalu banyak, yaitu dengan persentase $8.6 \%$ untuk reiterasi dan $3.4 \%$ untuk kolokasi. Beberapa kesalahan dalam penggunaan kohesi muncul dalam karangan. Kesalahan yang ditemukan berdampak pada nilai akhir mahasiswa pada tahapan pratindakan

Tabel 1.2 Jumlah Penggunaan Kohesi Benar dan Salah pada Tahapan Pratindakan

\begin{tabular}{|c|c|c|c|c|c|}
\hline No & $\begin{array}{l}\text { Kode } \\
\text { karangan }\end{array}$ & $\begin{array}{l}\text { Jumlah } \\
\text { Kohesi }\end{array}$ & $\begin{array}{l}\text { Kohesi } \\
\text { Salah }\end{array}$ & $\begin{array}{l}\text { Kohesi } \\
\text { Benar }\end{array}$ & $\begin{array}{l}\text { Nilai } \\
\text { Akhir }\end{array}$ \\
\hline (1) & (2) & (3) & (4) & (5) & (6) \\
\hline 1 & $\begin{array}{l}\text { PRA/KR- } \\
1\end{array}$ & 28 & 6 & 22 & 79 \\
\hline 2 & $\begin{array}{l}\text { PRA/KR- } \\
2\end{array}$ & 28 & 8 & 20 & 71 \\
\hline 3 & $\begin{array}{l}\text { PRA/KR- } \\
3\end{array}$ & 25 & 7 & 18 & 72 \\
\hline 4 & $\begin{array}{l}\text { PRA/KR- } \\
4\end{array}$ & 14 & 3 & 11 & 79 \\
\hline 5 & $\begin{array}{l}\text { PRA/KR- } \\
5\end{array}$ & 38 & 10 & 28 & 74 \\
\hline 6 & $\begin{array}{l}\text { PRA/KR- } \\
6\end{array}$ & 29 & 5 & 24 & 83 \\
\hline 7 & $\begin{array}{l}\text { PRA/KR- } \\
7\end{array}$ & 40 & 11 & 29 & 73 \\
\hline 8 & $\begin{array}{l}\text { PRA/KR- } \\
8\end{array}$ & 74 & 19 & 55 & 74 \\
\hline 9 & $\begin{array}{l}\text { PRA/KR- } \\
9\end{array}$ & 36 & 6 & 30 & 83 \\
\hline 10 & $\begin{array}{l}\text { PRA/KR- } \\
10\end{array}$ & 46 & 9 & 37 & 80 \\
\hline 11 & $\begin{array}{l}\text { PRA/KR- } \\
11\end{array}$ & 50 & 7 & 43 & 86 \\
\hline 12 & $\begin{array}{l}\text { PRA/KR- } \\
12\end{array}$ & 25 & 4 & 21 & 84 \\
\hline 13 & $\begin{array}{l}\text { PRA/KR- } \\
13\end{array}$ & 58 & 9 & 49 & 84 \\
\hline 14 & $\begin{array}{l}\text { PRA/KR- } \\
14\end{array}$ & 32 & 10 & 22 & 69 \\
\hline 15 & $\begin{array}{l}\text { PRA/KR- } \\
15\end{array}$ & 35 & 5 & 30 & 86 \\
\hline \multicolumn{2}{|c|}{ Jumlah } & 558 & 119 & 439 & 1.177 \\
\hline \multicolumn{4}{|c|}{ Nilai Rerata } & \multicolumn{2}{|c|}{78} \\
\hline
\end{tabular}

Berdasarkan data tersebut dapat diamati bahwa jumlah penggunaan kohesi pada seluruh karangan adalah 558 buah kohesi gramatikal dan 
leksikal yang terdiri atas 119 kohesi yang salah dan 439 penggunaan kohesi yang benar. Total nilai akhir yang diperoleh oleh mahasiswa adalah 1.117 dengan rerata berjumlah 78. Apabila dikonversikan, nilai tersebut dapat digolongkan B (baik). Namun, hasil tersebut tentu belum dapat dikatakan cukup untuk merepresentasikan keberhasilan mahasiswa menghasilhan karangan yang padu dan berterima.

\section{Analisis Kualitatif Pratindakan}

Analisis kualitatif dimaksudkan untuk menjabarkan hasil analisis data sehingga kesalahan yang ditemukan dapat diamati secara jelas. Beberapa temuan kesalahan penggunaan kohesi gramatikal dan leksikal dapat dijabarkan sebagai berikut.

\section{Kesalahan Penggunaan Referensi}

Referensi merupakan salah satu peranti kohesi yang merupakan satuan gramatikal yang menggantikan satuan gramatikal lainnya dalam sebuah teks. Referensi juga dapat diartikan sebagai sebuah pengacuan. Contoh kesalahan penggunaan referensi oleh mahasiswa Semester IV IKIP Sarasawati Tabanan adalah sebagai berikut.

I don't agree about this because the social media make wasted time $\left(14^{\text {th }}\right.$ line. Code PRA/KR-3)

(Saya tidak setuju dengan ini karena media sosial menghabiskan waktu (baris ke-14 kode PRA/KR-3)

Pada kutipan karangan di atas, penulis menggunakan kata this yang dimaksudkan sebagai pengacuan terhadap kata sebelumnya. Padahal, penulis belum menjelaskan kata, frasa, atau klausa yang diacu oleh kata ini. Hal ini akan menimbulkan kejanggalan bagi pembaca karena pengacuan yang diberikan menjadi tidak jelas. Oleh karena itu, pada kutipan ini penulis sebaiknya tidak menggunakan referensi demonstratif, tetapi menggunakan bentuk asli kata, frasa, atau klausa yang diacu. Berdasarkan isi karangan, perbaikan yang dapat diberikan adalah seperti di bawah ini.

I don't agree about the use of social media because it make wasted time $\left(14^{\text {th }}\right.$ line. Code PRA/KR-3)

(Saya tidak setuju dengan penggunaan media sosial karena hal ini menghabiskan waktu (baris ke-14 kode PRA/KR-3)

\section{Kesalahan Penggunaan Konjungsi}

Konjungsi (conjunction) merupakan salah satu peranti kohesi yang berfungsi menghubungkan frasa, klausa, atau kalimat satu dengan lainnya. Beberapa hasil tulisan mahasiswa di bawah ini memperlihatkan beberapa kekeliruan penggunaan konjungsi yang menyebabkan kalimat menjadi tidak padu.

By utilizing this site with the optimal quality, students learning will be much better and if students use it excessively will have a negative impact with the development of students learning quality. $\left(9^{\text {th }}\right.$ line/code: PRA/KR-3)

(Dengan menggunakan situs ini disertai dengan kualitas optimal, pembelajaran siswa akan jauh lebih baik dan apabila siswa menggunakan secara berlebihan akan memberikan dampak negatif terhadap perkembangan kualitas pembelajaran siswa) (baris ke-9 line/code: $P R A / K R-3)$

Penggunaan konjungsi and di antara dua klausa tidak tepat karena dua klausa yang dihubungkan bersifat kontradiktif. Klausa pertama menjelaskan penggunaan internet yang berisfat positif, sementara klausa berikutnya menjelaskan penggunaan internet yang berlebihan. Dua klausa yang bersifat kontras tersebut tidak dapat dihubungkan dengan konjungsi and sehingga revisi yang dapat diberikan terhadap kesalahan dalam kalimat tersebut adalah seperti berikut.

By utilizing this site with the optimal quality of students learning will be much better yet if 
students use it excessively will have a negative impact with the development of students learning quality $\left(9^{\text {th }}\right.$ line/code: PRA/KR-3)

(Dengan menggunakan situs ini disertai dengan kualitas optimal, pembelajaran siswa akan jauh lebih baik, tetapi apabila siswa menggunakan secara berlebihan akan memberikan dampak negatif terhadap perkembangan kualitas pembelajaran siswa) (baris ke-9 line/code: $P R A / K R-3)$

\section{Refleksi}

Hasil analisis karangan menunjukkan bahwa kemampuan mahasiswa dalam menggunakan alat-alat kohesi, baik kohesi gramatikal maupun leksikal, belum maksimal. Dengan demikian, perlu adanya penerapan teknik tertentu untuk meningkatkan kualitas karangan mahasiswa. Dalam penelitian ini digunakan teknik graphic organizer.

\section{Penggunaan Peranti Kohesi Gramatikal dan Leksikal Karangan Mahasiswa pada Siklus 1}

Tahapan ini merupakan tahapan penelitian kedua yang dilakukan setelah tahapan pratindakan. Tahapan pratindakan menunjukkan hasil analisis karangan mahasiswa yang mengandung banyak kesalahan penggunaan kohesi gramatikal dan leksikal. Hasil analisis tersebut menjadi dasar pengaplikasian siklus 1 pada pembelajaran menulis.

\section{Implementasi Siklus 1}

Pada tahapan kedua ini dilakukan pengambilan data melalui kegiatan menulis dan dokumentasi. Pada tahapan ini mahasiswa diberikan pemahaman mengenai penerapan teknik graphic organizer kemudian mahasiswa diinstruksikan untuk membuat karangan dengan tema bebas berdasarkan graphic organizer yang telah dibuat.

\section{Analisis Kuantitatif Siklus 1}

Hasil karangan mahasiswa pada siklus 1 dianalisis dan dijabarkan dalam bentuk tabel penilaian yang terdiri atas jumlah penggunaan kohesi beserta persentase penggunaannya

Tabel 2.1 Penggunaan Peranti Kohesi Karangan Mahasiswa pada Siklus 1

\begin{tabular}{|c|c|c|c|c|}
\hline No & $\begin{array}{l}\text { Peranti } \\
\text { kohesi } \\
\text { gramatikal } \\
\text { dan leksikal }\end{array}$ & $\begin{array}{l}\text { Jumlah } \\
\text { Penggu } \\
\text { naan }\end{array}$ & $\begin{array}{l}\text { Perse } \\
\text { ntase }\end{array}$ & $\begin{array}{l}\text { Jumlah } \\
\text { Kalimat }\end{array}$ \\
\hline (1) & (2) & (3) & (4) & (5) \\
\hline 1 & Reference & 377 & $56 \%$ & \multirow{7}{*}{$\begin{array}{c}3.702 \\
\text { Kalimat }\end{array}$} \\
\hline 2 & Substitution & 4 & $1 \%$ & \\
\hline 3 & Ellipsis & 3 & $0 \%$ & \\
\hline 4 & Conjunction & 222 & $33 \%$ & \\
\hline 5 & Reiteration & 43 & $6 \%$ & \\
\hline 6 & Collocation & 21 & $3 \%$ & \\
\hline & Jumlah & 670 & $100 \%$ & \\
\hline
\end{tabular}

Apabila dibandingkan dengan hasil pratindakan, terdapat kecenderungan peningkatan jumlah dan persentase penggunaan kohesi. Jumlah kalimat yang diproduksi mahasiswa dalam karangan mencapai 3.702 kalimat sedangkan sebelumnya hanya berjumlah 195 kalimat. Referensi dan konjungsi masih mendominasi penggunaan kohesi dalam karangan mahasiswa. Sementara penggunaan substitusi dan elipsis masih tergolong kecil meskipun terdapat peningkatan penggunaan dibandingkan dengan tahapan pratindakan. Penggunaan kohesi leksikal cenderung stagnan dengan persentase reiterasi sebanyak $6 \%$ dan kolokasi sebanyak $3 \%$ 
Tabel 2.2 Jumlah Penggunaan Kohesi bBenar dan Salah pada Siklus 1

Berdasarkan hasil analisis, terlihat peningkatan penggunaan kohesi dari sebelumnya berjumlah 558 pada tahapan pratindakan, meningkat menjadi 697 kohesi. Penggunaan kohesi yang benar meningkat sebanyak 610 dari jumlah sebelumnya sebanyak 439. Sementara, penggunaan kohesi yang salah mengalami penurunan menjadi 87 dibandingkan dengan sebelumnya yang berjumlah 119. Perubahan ini tentu mempengaruhi nilai akhir mahasiswa. Total nilai akhir yang diperoleh oleh mahasiswa adalah 1.323 dengan rerata berjumlah 88.2. Apabila dikonversikan, nilai tersebut dapat dikonversikan menjadi nilai A (amat baik).

\section{Analisis Kualitatif Siklus 1}

Penggunaan graphic organizer sangat membantu mahasiswa dalam menuangkan ide-ide dan menyusunnya dalam bentuk paragraf. Namun, berdasarkan hasil analisis, diketahui masih terdapat kesalahan-kesalahan yang muncul dalam menggunakan alat-alat kohesi. Beberapa temuan kesalahan penggunaan kohesi gramatikal dan leksikal dapat dijabarkan sebagai berikut.

\section{Kesalahan Penggunaan Substitusi}

Substitusi mengacu hubungan gramatikal, yaitu unsur pengganti menggantikan kata yang maknanya sama sekali berbeda dengan kata yang diacunya. Dalam karangan mahasiswa terdapat kesalahan penggunaan substitusi sebagai berikut.

Tabanan is one of biggest regency in Bali $\left(9^{\text {th }}\right.$ line/code: $S K-1 / K R 3)$

(Tabanan adalah salah satu kabupaten yang terbesar di Bali) (Baris ke-9/code: $S K-1 / K R 3$ )

Kutipan karangan di atas mengandung pengacu substitusi one yang merujuk pada kata Tabanan. Kata one tersebut diikuti oleh superlative degree (tingkatan superlatif/paling) yang menyatakan bahwa Tabanan sebagai kota terbesar. Penggunaan kata one tidak tepat untuk digunakan karena cenderung membentuk makna lebih dari satu atau pengklasifikasian antara satu hal dengan hal lain. Sementara, penggunaan kata

\begin{tabular}{llcccc}
\hline No & $\begin{array}{l}\text { Kode } \\
\text { karangan }\end{array}$ & $\begin{array}{l}\text { Jumlah } \\
\text { Kohesi }\end{array}$ & $\begin{array}{l}\text { kohesi } \\
\text { salah }\end{array}$ & $\begin{array}{l}\text { kohesi } \\
\text { benar }\end{array}$ & $\begin{array}{l}\text { Nilai } \\
\text { Akhir }\end{array}$ \\
\hline $\mathbf{- 1}$ & $\mathbf{- 2}$ & $\mathbf{- 3}$ & $\mathbf{- 4}$ & $\mathbf{- 5}$ & $\mathbf{- 6}$ \\
\hline 1 & PRA/KR-1 & 27 & 4 & 23 & 85 \\
\hline 2 & PRA/KR-2 & 29 & 2 & 27 & 93 \\
\hline 3 & PRA/KR-3 & 25 & 2 & 23 & 92 \\
\hline 4 & PRA/KR-4 & 32 & 4 & 28 & 88 \\
\hline 5 & PRA/KR-5 & 50 & 5 & 45 & 90 \\
\hline 6 & PRA/KR-6 & 34 & 5 & 29 & 85 \\
\hline 7 & PRA/KR-7 & 44 & 6 & 38 & 86 \\
\hline 8 & PRA/KR-8 & 44 & 5 & 39 & 89 \\
\hline 9 & PRA/KR-9 & 49 & 5 & 44 & 90 \\
\hline 10 & PRA/KR-10 & 35 & 6 & 29 & 83 \\
\hline 11 & PRA/KR-11 & 24 & 1 & 23 & 96 \\
\hline 12 & PRA/KR-12 & 111 & 17 & 94 & 85 \\
\hline 13 & PRA/KR-13 & 96 & 13 & 83 & 86 \\
\hline 14 & PRA/KR-14 & 53 & 6 & 47 & 89 \\
\hline 15 & PRA/KR-15 & 35 & 5 & 30 & 86 \\
\hline Jumlah & 697 & 87 & 610 & 1323 \\
\hline \multicolumn{7}{l}{} & Nilai Rerata & & & 88.2 \\
\hline
\end{tabular}

biggest bermakna paling besar, yang berarti tidak akan ada tingkat perbandingan lainnya. Apabila suatu kata sifat dibentuk menjadi superlative (tingkat perbandingan paling), kata tersebut harus didahului oleh referensi demostratif the. Dengan demikian, perlu adanya perubahan pada kalimat di atas, yakni sebagai berikut.

Tabanan is the biggest regency in Bali $\left(9^{\text {th }}\right.$ line/code:SK-1/KR3)

Tabanan adalah salah satu kabupaten yang terbesar di Bali (baris ke-9/code: $S K-1 / K R 3$ )

Kesalahan Penggunaan Kohesi Leksikal

Kohesi leksikal berkaitan sangat erat dengan pemilihan kata dalam sebuah teks. Penggunaan leksikon yang salah ditemukan pada salah satu karangan mahasiswa. Kesalahan tersebut merupakan kesalahan penggunaan antonim kata, yakni sebagai berikut.

The social media is not only used by adults but also the underage students ( $4^{\text {th }}$ line)

(Media sosial tidak hanya digunakan oleh orang dewasa tetapi juga murid di bawah umur. 
Penggunaan kata underage students pada kalimat di atas dianggap tidak tepat karena bukan merupakan antonim dari kata sebelumnya. Penulis ingin menciptakan pernyataan yang bersifat kontradiktif dengan mengabil dua objek yang berlawanan, yakni adults dan underage students. Namun, dua kata tersebut tidak memiliki hubungan antonim sehingga tidak tepat digunakan dalam kalimat tersebut. Antonim kata aduts adalah children. Dengan demikian perbaikan yang dapat diberikan untuk kalimat di atas adalah sebagai berikut.

The social media is not only used by adults but also the underage children ( $4^{\text {th }}$ line)

(Media sosial tidak hanya digunakan oleh orang dewasa tetapi juga anak-anak di bawah umur.

\section{Refleksi Penerapan Siklus 1}

Berdasarkan hasil analisis karangan mahasiswa, dapat dicermati bahwa terdapat peningkatan performa menulis mahasiswa, baik dari segi penggunaan alat-alat kohesi gramatikal dan leksikal maupun dari segi pengembangan kata. Penerapan teknik graphic organizer memperlihatkan hasil yang signifikan terhadap kemampuan mahasiswa menggunakan alat-alat kohesi.

Grafik 4.3 Perbandingan Penggunaan Kohesi pada Tahapan Pratindakan dan Siklus 1

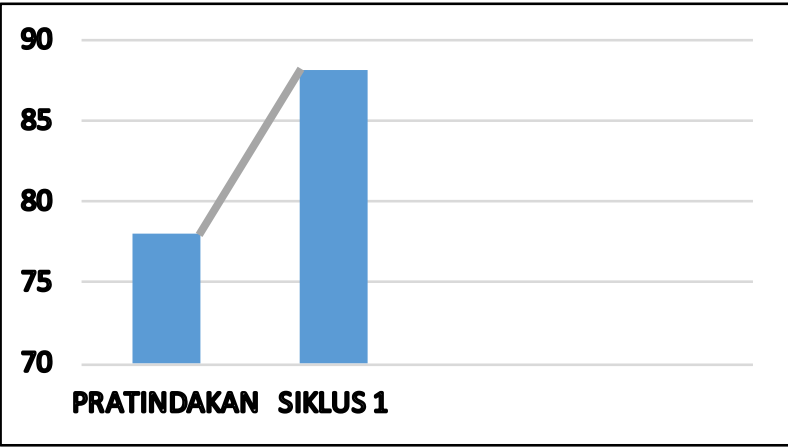

Berdasarkan grafik di atas diketahui bahw nilai rerata mahasiswa mengalami peningkatan menjadi 88.2 pada siklus 1 setelah penerapan teknik graphic organizer, sedangkan sebelumnya hanya mendapat rerata 78. Hasil penerapan siklus 1 ini menjadi bahan acuan untuk menerapkan siklus 2 .

\section{Penggunaan Peranti Kohesi Gramatikal dan Leksikal Karangan Mahasiswa pada Siklus 2}

\section{Implementasi Siklus 2}

Pengimplemetasian siklus 2 tidak jauh berbeda dengan siklus 1. Pada tahapan ini dilakukan pengambilan data melalui kegiatan menulis dan dokumentasi. Mahasiswa diintruksikan untuk kembali membuat graphic organizer kemudian menulis karangan dengan tema bebas sesuai dengan graphic organizer yang telah dibuat.

\section{Analisis Kuantitatif Siklus 2}

Berdasarkan hasil analisis karangan mahasiswa pada tahapan siklus 2, terdapat peningkatan penggunaan kohesi gramatikal dan leksikal dalam karangan mahasiswa. Jumlah penggunaan dan persentase penggunaan alat-alat kohesi dijabarkan pada tabel di bawah ini

Tabel 3.1 Penggunaan Peranti Kohesi Karangan Mahasiswa pada Siklus 2

\begin{tabular}{|c|c|c|c|c|}
\hline No & $\begin{array}{l}\text { Peranti kohesi } \\
\text { gramatikal } \\
\text { dan leksikal }\end{array}$ & $\begin{array}{l}\text { Jumlah } \\
\text { Penggu } \\
\text { naan }\end{array}$ & $\begin{array}{l}\text { Persen } \\
\text { tase }\end{array}$ & $\begin{array}{l}\text { Jumlah } \\
\text { Kalimat }\end{array}$ \\
\hline (1) & (2) & (3) & (4) & (5) \\
\hline 1 & Reference & 358 & $49 \%$ & \multirow{7}{*}{$\begin{array}{c}3.842 \\
\text { Kalimat }\end{array}$} \\
\hline 2 & Substitution & 7 & $1 \%$ & \\
\hline 3 & Ellipsis & 3 & $0 \%$ & \\
\hline 4 & Conjunction & 281 & $39 \%$ & \\
\hline 5 & Reiteration & 60 & $8 \%$ & \\
\hline 6 & Collocation & 17 & $2 \%$ & \\
\hline & Jumlah & 726 & $100 \%$ & \\
\hline
\end{tabular}

Berdasarkan data di atas, diketahui terdapat peningkatan penggunaan kohesi gramatikal dan kohesi leksikal pada Siklus 2 dibandingkan dengan hasil yang diperoleh pada siklus 1 . Sebanyak 726 kohesi digunakan dari 3.842 satuan topik. Referensi menjadi kohesi terbanyak yang muncul dalam karangan mahasiswa dengan 
persentase $49 \%$. Konjungsi menempati urutan kedua kohesi terbanyak yang muncul dalam karangan dengan persentase 39\%. Penggunaan substitusi dalam karangan mahasiswa mengalami peningkatan meskipun tidak mengubah persentase yang tercatat pada siklus 1 . Sementara, penggunaan ellipsis, reiterasi, dan kolokasi cenderung stagnan. Selain perubahan persentase penggunaan, jumlah penggunaan kohesi yang benar pada siklus 2 meningkat dibandingkan dengan siklus 1 sedangkan penggunaan kohesi yang salah mengalami penurunan. Hal ini berdampak pada nilai akhir yang diperoleh mahasiswa.

Tabel 4.8 Jumlah Penggunaan Kohesi Benar dan Salah pada Siklus 2

\begin{tabular}{cccccc}
\hline No & $\begin{array}{c}\text { Kode } \\
\text { karangan }\end{array}$ & $\begin{array}{c}\text { Jumlah } \\
\text { Kohesi }\end{array}$ & $\begin{array}{c}\text { Kohesi } \\
\text { Salah }\end{array}$ & $\begin{array}{c}\text { Kohesi } \\
\text { Benar }\end{array}$ & $\begin{array}{c}\text { Nilai } \\
\text { Akhir }\end{array}$ \\
\hline-1 & -2 & -3 & -4 & -5 & -6 \\
\hline 1 & PRA/KR-1 & 35 & 6 & 29 & 83 \\
\hline 2 & PRA/KR-2 & 42 & 3 & 39 & 93 \\
\hline 3 & PRA/KR-3 & 72 & 5 & 67 & 93 \\
\hline 4 & PRA/KR-4 & 43 & 3 & 40 & 93 \\
\hline 5 & PRA/KR-5 & 43 & 2 & 41 & 95 \\
\hline 6 & PRA/KR-6 & 31 & 5 & 26 & 84 \\
\hline 7 & PRA/KR-7 & 63 & 7 & 56 & 89 \\
\hline 8 & PRA/KR-8 & 55 & 6 & 49 & 89 \\
\hline 9 & PRA/KR-9 & 48 & 8 & 40 & 83 \\
\hline 10 & PRA/KR-10 & 59 & 3 & 56 & 95 \\
\hline 11 & PRA/KR-11 & 29 & 2 & 27 & 93 \\
\hline 12 & PRA/KR-12 & 49 & 5 & 44 & 90 \\
\hline 13 & PRA/KR-13 & 68 & 8 & 60 & 88 \\
\hline 14 & PRA/KR-14 & 43 & 7 & 36 & 84 \\
\hline 15 & PRA/KR-15 & 46 & 5 & 41 & 89 \\
\hline \multicolumn{7}{r}{ Jumlah } & 726 & 75 & 651 & 1.341 \\
\hline & & & & & \\
\hline
\end{tabular}

Berdasarkan data pada tabel di atas, terlihat peningkatan penggunaan kohesi dari siklus 1 yang berjumlah 697 kohesi meningkat menjadi 726 kohesi pada pelaksanaan siklus 2. Hasil ini diperoleh setelah dilakukan pengklasifikasian penggunaan kohesi yang benar dan kohesi yang salah. Hasil analisis pada siklus 2 ini menunjukkan peningkatan penggunaan kohesi yang benar sebanyak 651 dari sebelumnya berjumlah 610. Perkembangan keterampilan menulis mahasiswa juga ditunjukkan dengan penurunan penggunaan kohesi yang salah yakni berjumlah 75 buah dari sebelumnya berjumlah 87 buah. Perubahan ini berdampak terhadap pemerolehan nilai akhir mahasiswa. Total nilai akhir yang diperoleh mahasiswa berjumlah 1.341 dengan rerata sebesar 89. Apabila dikonversikan, rerata nilai tersebut tergolong dalam predikat $\mathrm{A}$ (amat baik). Pemerolehan nilai ini meningkat dari sebelumnya yakni 1.323 dengan rerata sebesar 88.2.

\section{Analisis Kualitatif Siklus 2}

Berdasarkan hasil analisis, diketahui terdapat peningkatan kemampuan menggunakan kohesi. Namun, masih terdapat kesalahan yang muncul dalam menggunakan alat-alat kohesi. Salah satu kesalahan yang muncul pada siklus 2 adalah penggunaan konjungsi and yang terdapat dalam kutipan karangan berikut.

And now imagine how unfortunate the diligent students who always come to the school, follow the exam, and fail. ( $8^{\text {th }}$ line)

Dan sekarang bayangkan bagaimana ruginya mahasiswa rajin yang sealu datang ke sekolah, mengikuti ujian, dan gagal

Ketidaktepatan penggunaan and muncul pada kedua penggunaan konjungsi tersebut. Kesalahan pertama adalah penggunaan konjungsi and diletakkan di awal kalimat. Hal ini tentu tidak sesuai dengan aturan bahasa Inggris bahwa konjungsi koordinatif termasuk and di dalamnya tidak diperbolehkan diletakkan di awal kalimat. Hal ini disebabkan fungsi and yang menghubungkan dua kata, frasa, atau klausa yang setara dalam kalimat. Oleh karena itu, kata and harus digantikan dengan konjungsi lain. Dalam hal ini konjungsi yang tepat digunakan adalah konjungsi temporal (temporal conjunction). 
Kesalahan selanjuntya adalah penggunaan and untuk menghubungkan frasa verbal (verb phrase). Frasa yang dihubungkan adalah come to the school (datang ke sekolah), follow the exam (mengikuti ujian), and fail (gagal). Kesalahan kata and terletak pada hubungan frasa. Frasa verbal pertama dan kedua bersifat positif, sementara frasa ketiga menunjukkan sifat negatif sehingga hubungan antara frasa pertama dan kedua dengan frasa ketiga bersifat kontradiktif. Dengan demikian, penggunaan and tidak tepat untuk menggambarkan hubungan adversatif atau kontradiktif dalam kalimat sehingga harus diperbaiki dengan menambahkan konjungsi adversatif (adversative conjunction). Perbaikan untuk kesalahan-kesalahan tersebut dapat di amati sebagai berikut.

Then, let us imagine how unfortunate the diligent students who always come to the school, follow the exam, but then fail. ( $8^{\text {th }}$ line) Lalu, mari kita bayangkan, bagaimana ruginya mahasiswa rajin yang selalu datang ke sekolah, mengikuti ujian, tetapi gagal. $\left(8^{\text {th }}\right.$ line $)$

\section{Refleksi Penerapan Siklus 2}

Pelaksanaan siklus 2 dimaksudkan untuk membuat mahasiswa lebih memahami penggunaan alat-alat kohesi melalui teknik graphic organizer. Berdasarkan hasil analisis karangan, terlihat perkembangan mahasiswa dalam penguasaan keterampilan menulis yang ditandai dengan persentase jumlah kesalahan penggunaan alat-alat kohesi leksikal dan gramatikal yang semakin menurun serta peningkatan pemerolehan nilai akhir. Pemerolehan nilai akhir mahasiswa pada siklus 1 maupun siklus 2 menunjukkan progres yang signifikan dibandingkan dengan tahapan pratindakan. Pada tahapan pratindakan, mahasiswa hanya mendapatkan rerata nilai 78 dengan predikat baik. Sementara, pada dua tahapanan selanjutnya, yakni siklus 1 dan siklus 2 pemerolehan rerata nilai mahasiswa adalah 88.2 dan 89 dengan predikat A (amat baik). Hasil ini dapat diamati secara jelas pada grafik di bawah ini

Grafik 3.1 Perbandingan Penggunaan Kohesi pada Tahapan Pratindakan, Siklus 1, dan Siklus 2

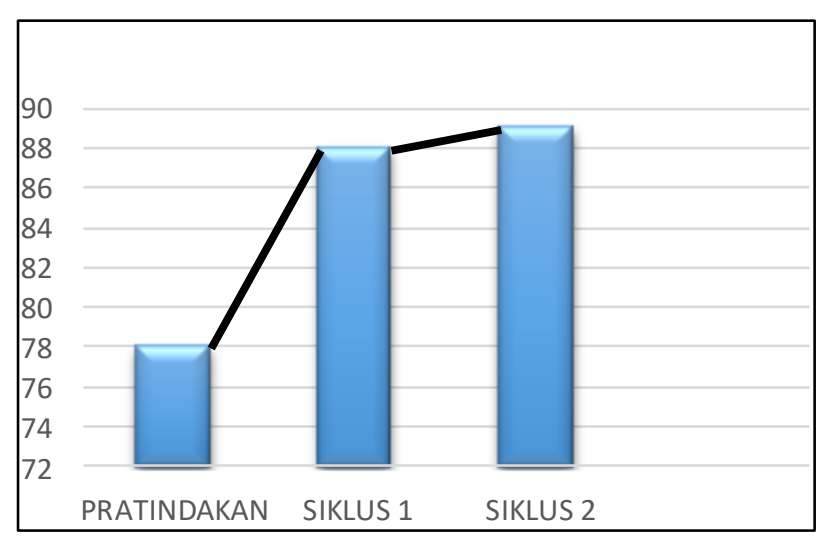

Berdasarkan grafik di atas, terlihat perkembangan yang cukup signifikan dari tahapan Pratindakan menuju siklus 1 dan siklus 2. Ini menunjukkan bahwa penerapan teknik graphic organizer dapat membantu mahasiswa menghasilkan karya tulis dengan menggunakan alat-alat kohesi gramatikal dan leksikal dengan tepat guna dan berterima

\section{Simpulan}

Tahapan pratindakan menjadi refleksi kelemahan mahasiswa dalam memahami dan menggunakan alat-alat kohesi yang terdiri atas kohesi leksikal dan kohesi gramatikal dalam menulis karangan. Persepsi ini didukung oleh pemerolehan nilai rerata mahasiswa yang berada pada angka 78 dengan penggunan kohesi sebanyak 558. Dari keseluruhan total penggunaan kohesi sebanyak 558, terdapat 119 penggunaan kohesi yang salah. Hasil kuesioner yang terkumpul pun menunjukkan fakta bahwa hampir seluruh mahasiswa tidak memahami unsur-unsur kohesi dalam tulisan. Selain itu, proses pembelajaran yang bersifat konservatif tanpa adanya metode atau teknik pendukung menjadi salah satu faktor yang menghambat mahasiswa dalam menghasilkan sebuah tulisan. Salah satu 
teknik yang dapat digunakan dalam kegiatan menulis adalah teknik graphic organizer. Teknik ini terbukti mampu meningkatkan penggunaan kohesi gramatikal dan leksikal dalam karangan mahasiswa. Pada tahapan pratindakan mahasiswa memperoleh nilai rerata 78 dengan predikat baik (B). Setelah penerapan siklus 1 , nilai rerata mahasiswa meningkat secara signifikan, yakni sebesar 88.2 dengan predikat amat baik (A). Pada tahapan akhir, yakni siklus 2 nilai mahasiswa meningkat sebanyak 0,8 poin sehingga nilai rerata menjadi 89 dengan predikat amat baik (A).

\section{Daftar Pustaka}

Bereiter C. (1994) Constructivism, socioculturalism, and Popper's World 3. Educational Researcher 23(7): 21-23.

Brown, H.D. 2007. Teaching by Principles. an Interactive Approach to Language Pedagogy. (3rd ed). New York: Addison Wesley Longman.

Celce-Murcia, Marianne \&Olshtain, Elite. 2000. Discourse and Context in language Teaching, Cambridge: Cambridge University Press

Chaer, Abdul. 2008. Pengantar Semantik Bahasa Indonesia. Jakarta: RinekaCipta.

Clark, A. 2007. GOs and the School Library Program. University of Alberta Department of Elementary Education.

Connor and Farmer. 1990. "The Teaching of Topical Structure Analysis as a Revision Strategy for ESL Writers." In Kroll, Barbara (ed.) 1990. Second Language Writing: Research Insights for the Classroom. Cambridge: Cambridge University Press.
Davis, Lloyd and Susan McKay.1996. Structures and Strategies: An Introduction to Academic Writing. Macmillan Education Australia PTY LTD: 107 Moray Street South Melbourne 3205

Deuraman, Batayee. 2007. "Cohesion and Coherence in English Essays Written by Malaysian and Thai Medical Students". 2007 Southern Thailand English Language Teaching/Cultural Change Conference

Eggins, Suzanne. 1994. An Introduction to Systemic Functional Linguistics. London: Pintar.

Gie, The Liang. 1995. Pengantar Dunia KarangMengarang. Yogjakarta: Liberty.

Halliday, M.A.K. and Ruqaiya Hasan. 1976. Cohession In English. New York. Longman Group Limited.

Hastuti, Sri P.H. 1993. Pendidikan Bahasa Indonesia MDU 4208. Yogyakarta: UPP IKIP Yogyakarta.

Hussein, N.M. 2016. "Iraqi EFL College Students' Use of Cohesion in Narrative Essays". International Journal of Scientific and Educational Research (IJSER), 1(1), 99-118.

Indiyastini, Titik. 2006. "Referensi sebagai Alat Kohesi Paragraf Deskriptif dalam Bahasa Jawa". Dalam Widyaparwa. Tahun ke-34, Nomor 1 Juni 2006. Hal 35-53. Jakarta: Pusat Bahasa Departemen Pendididkan Nasional

James, Carl. 1998. Errors in Language and Use. London: Longman

Jiang, X., \& Grabe, W. 2007. Graphic Organizers in Reading Instruction: Research Findings and Issues. Reading in a Foreign Language, 19(1), 34-35. 
LINGUISTIKA, SEPTEMBER 2019

p-ISSN: 0854-9613

Vol. 26. No. 2

Karadeniz, Abdulkerim. 2017. "Cohesion and Coherence in Written Texts of Students of Faculty of Education". Journal of Education and Training Studies Vol. 5, No. 2; February 2017 ISSN 2324-805X E-ISSN 2324-8068 Published by Redfame Publishing URL: http://jets.redfame.com.

Widayati, Ani. 2008. "Penelitian Tindakan Kelas". Jurnal Pendidikan Akuntansi Indonesia Vol. VI No. 1 - Tahun 2008 Hal. 87 - 93 